\title{
A Review on Novel Approach towards the Methods for Detection of Growth Parameters in Plants
}

\author{
Qurat Ul Ain ${ }^{1}$, Saba Javed ${ }^{1}$, Syed Muhammad Ali Mardan Zaidi ${ }^{3 *}$, Liaqat Ali ${ }^{4}$, Muhammad Umair Dildar ${ }^{2}$, Faiza Nasim ${ }^{1}$ \\ ${ }^{1}$ Department of Biochemistry, University of agriculture, Faisalabad, Pakistan \\ ${ }^{2}$ Department of Seed Science \& Technology, University of agriculture, Faisalabad, Pakistan \\ ${ }^{3}$ Institute of Horticultural Sciences, University of Agriculture, Faisalabad, Pakistan \\ ${ }^{4}$ Department of Botany, University of Agriculture, Faisalabad, Pakistan
}

DOI: $10.36348 /$ sijb.2020.v03i06.003

| Received: 09.06.2020 | Accepted: 17.06.2020 | Published: 24.06 .2020

*Corresponding author: Syed Muhammad Ali Mardan Zaidi

\section{Abstract}

Plants species are most commonly used for metal phytoremediation in hydroponic as well as field experiments. The study remains unclear about methods measuring the growth parameters in Salix species. The aims of this review included the advanced methods that are used recently for measuring the growth parameters in Salix species. Inductively coupled plasma-optical emission spectroscopy is used to find out the concentration of plant phosphorus and cadmium. Nitrogen concentration detected by using the laboratory analyzer such as inductively coupled plasma-optical emission spectroscopy. Coomassie brilliant blue staining method is used commonly to determine the concentration of soluble proteins in plant samples. Biological activity of enzyme superoxide dismutase is measured by spectrophotometer at absorbance $560 \mathrm{~nm}$. Lipid peroxidation in plant tissues determined by measuring the malondialdehyde formation using the thiobarbituric acid method. This method is based on spectrophotometric principle and red-violet complex is formed by the formation of malondialdehyde. Root activity in plant tissues determined by using the triphenyltetrazolium chloride test. The absorbance is then measured by spectrophotometer at absorbance $485 \mathrm{~nm}$.

Keywords: Nitrogen, Phosphorus, hydroponic conditions, Carotenoids, phytoremediation.

\begin{abstract}
Copyright @ 2020: This is an open-access article distributed under the terms of the Creative Commons Attribution license which permits unrestricted use, distribution, and reproduction in any medium for non-commercial use (NonCommercial, or CC-BY-NC) provided the original author and source are credited.
\end{abstract}

\section{INTRODUCTION}

The quantification of chlorophyll in higher plants has been performed using a non-destructive chlorophyll meters such as flourometry, photo-acoustic spectroscopy, chromatographic techniques, and spectrophotometry[1]. With the advantages of intuitiveness, convenience, and ease, spectrophotometry has been the classic method for chlorophyll determination in the leaves of terrestrial plants and in chlorophyll determination of other photosynthetic organisms. Cadmium and nickel are acting as heavy toxic metal that affect the growth of plants by alternating the normal functioning mechanisms of plants. It also causes the environmental pollution that disturbed the natural ecosystem of environment[2]. It is produced by Industries that are the major source of environmental pollution. Its higher concentration in plants leads to toxicity and death of plant tissues[3] . It also interferes with mineral elements in plants by increasing the activity of enzyme such as superoxide dismutase. Cadmium enter into the root of plant cells by disturbing the overall growth of plants[4].
Inductively coupled plasma-optical emission spectroscopy used to find out the concentration of plant phosphorus and cadmium. It is used in the laboratory testing for detection of chemical elements in plant samples[5]. Inductively coupled plasma-optical emission spectroscopy used to find out the concentration of plant phosphorus and cadmium[6]. Coomassie brilliant blue staining method is used commonly to determine the concentration of soluble proteins in plant samples[7].

Phytoremediation is mostly commonly used method to remove toxic metals from the plants that are affected by heavy metals stress especially cadmium. Lipid peroxidation in plant tissues determined by measuring the malondialdehyde formation using the thiobarbituric acid method[8]. This method is based on spectrophotometric principle and red-violet complex is formed by the formation of malondialdehyde. Root activity in plant tissues determined by using the triphenyltetrazolium chloride test. Coomassie brilliant blue is a dye that bind with specific proteins in plant 
samples through ionic interactions and used for staining the specific proteins[9]. Phytoextraction is a method of phytoremediation that supported the plants for accumulating toxic metals in their special organs such as root system.

Salix is most commonly used for metal phytoremediation in hydroponic as well as field experiments. The common name of salix is wood that helpful for plants for metal decontamination[10]. Phytoextraction of heavy metals especially cadmium can be improved by supplying the optimum concentration of elements such as nitrogen and phosphorus. Enrichment of nitrogen and phosphorus in proper concentration provide advantage to phytoremediation plants for removal of cadmium. This process leads to trap toxic metals and finally degraded them[11].

The sample preparation included that plant sample cuttings transferred to a normal water tank with six to ten small chambers. Hoagland nutrient provided and proper nitrogen and phosphorus concentrations regulated[12]. Then root cuttings cultivated in a greenhouse under a photoperiod of $16 \mathrm{~h}$ temperature at $25{ }^{\circ} \mathrm{C} / 20{ }^{\circ} \mathrm{C}$ in day/night[13] . After 6 weeks, cuttings harvested and root cuttings selected randomly. Root cuttings harvested and deionized water used to wash them. Root cutting further divided into roots, and initial cuttings. Growth measurements such as length, number, dry and fresh weights of shoot and root measured precise[14].When suitable amount of nitrogen and phosphorus added to the growth medium, cadmium accumulation started effectively seen in plants such as Epilobiumlaxum Royle. Cadmium accumulation increases in when plants grown in hydroponic conditions by supplying the nutrients[15]. Proper supplementation of ammonium ion $\left(\mathrm{NH}^{+}\right)$increases the trapping or accumulation of cadmium in some plants such as sunflower, potato when these plants ideally grown in soils. It has been observed that application of nitrogen fertilizers lead to effective binding to cadmium and decontaminated them seen as in S. plumbizincicola[16].

The study remains unclear about methods measuring the growth parameters in Salix species. The aims of this review most included the advanced methods that are used recently for measuring the growth parameters in Salix species. Accumulation of nitrogen and phosphorus is crucial and important for investigating the Salix spp cuttings. Mechanism remains unclear how phytoremediation plants show physical responses by nutritional supplementation of nitrogen and phosphorus under hydroponic conditions. Changes the concentration of nitrogen and phosphorus for trapping of cadmium using salix plants not completely understood.

\section{Detection of Phosphorus and cadmium Concentrations \\ ICP-OES basically used to find the} concentration of elements epically heavy metals in a particular sample[17]. It is used in the laboratory testing for detection of chemical elements in plant samples. Inductively coupled plasma-optical emission spectroscopy based of principle of emission spectroscopy in which plasma is produced by excitation of the atoms. Inductively coupled plasma-optical emission spectroscopy used to find out the concentration of plant phosphorus and cadmium. Plants samples such a root, shoot and initial cutting grinded[18]. Nitrogen concentration detected by using the laboratory analyzer such as inductively coupled plasma-optical emission spectroscopy. The most commonly gas used is the argon gas in Inductively coupled plasma-optical emission spectroscopy[19].

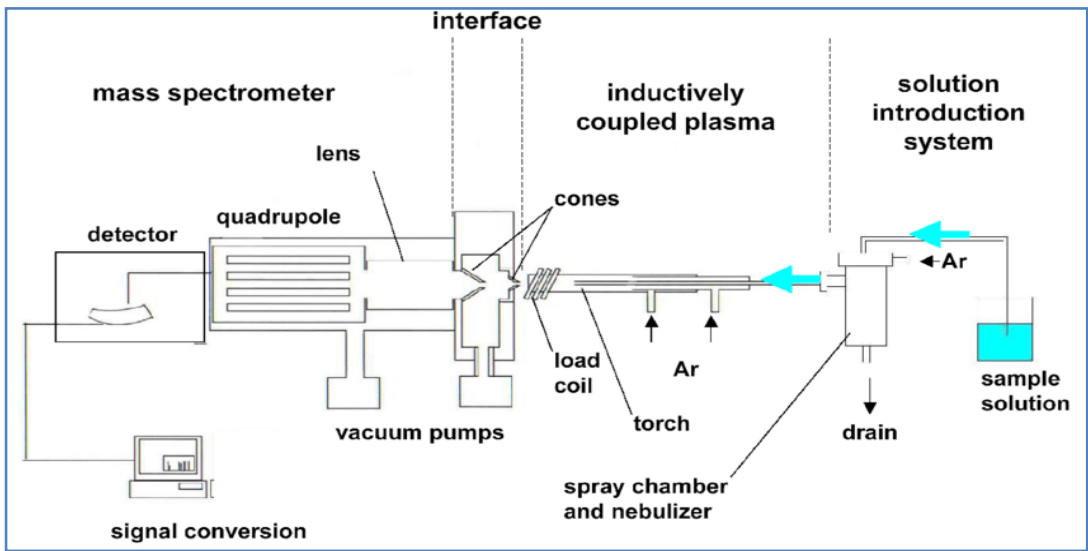

Fig-1: Inductively coupled plasma-optical emission spectroscopy for detection of phosphorus and cadmium and Nitrogen

\section{Detection of Soluble Proteins}

Coomassie brilliant blue staining method is used commonly to determine the concentration of soluble proteins in plant samples. Coomassie brilliant blue is a dye that bind with specific proteins in plant samples through ionic interactions and used for staining the specific proteins. The bands appear as when a dye coomassie brilliant blue gently apply on protein sample[20]. The proteins that contains the slices in the form of gel that incubated with enzyme such as trypsin. 
Biological activity of enzyme superoxide dismutase measured by spectrophotometer at absorbance $560 \mathrm{~nm}$. Superoxide dismutase has function against free radicals formation in plants by preventing the long chain that causes free radicals formation. Peroxidase enzyme activity also determined with spectrophotometer at absorbance $560 \mathrm{~nm}$. Peroxidase enzyme has also functions in regulating the oxygen reactive species in plant tissues and thus helps in plant defense mechanism[21].

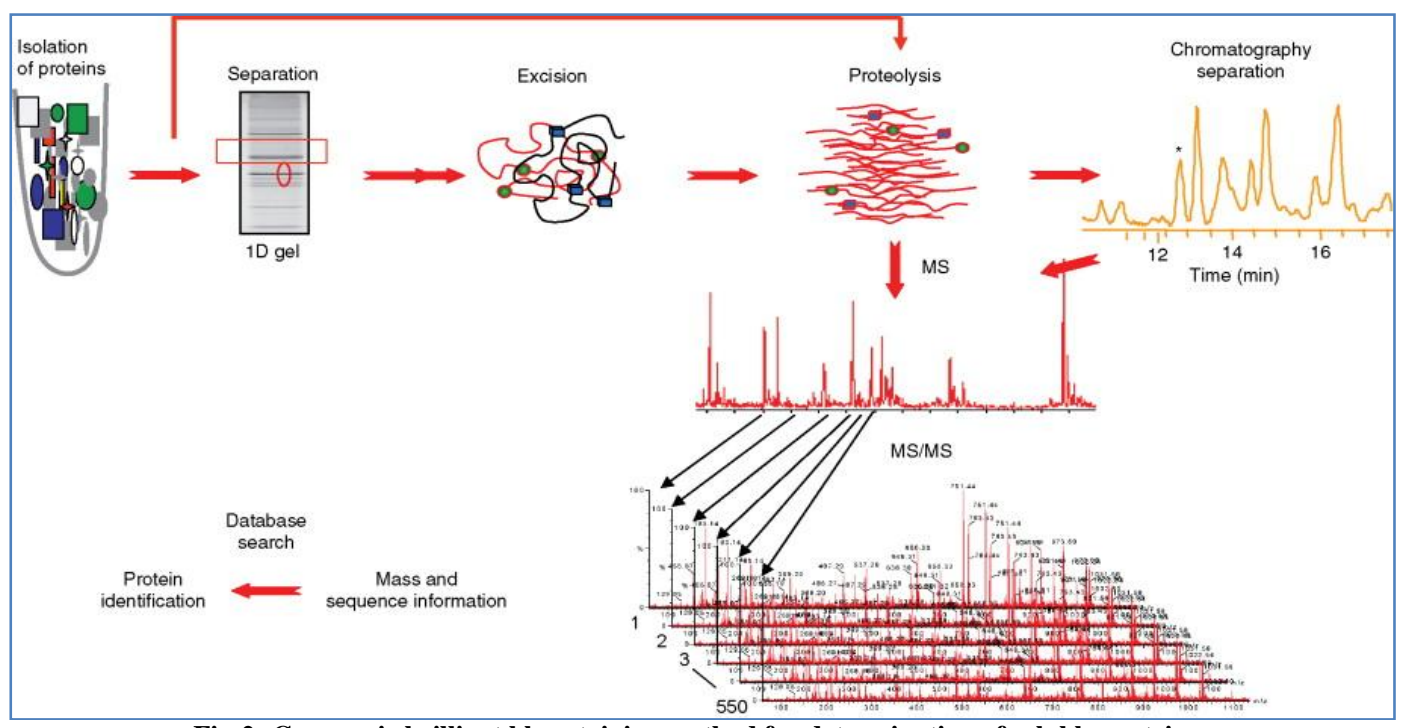

Fig-2: Coomassie brilliant blue staining method for determination of soluble proteins.

\section{Measurement of Lipid Peroxidation}

Lipid peroxidation in plant tissues determined by measuring the malondialdehyde formation using the thiobarbituric acid method. This method is based on spectrophotometric principle and red-violet complex is formed by the formation of malondialdehyde[22]. The plants samples collected for testing the lipid contents in specific tissues. TBA reagent bound to the plant sample. As a result of this reaction, dark red colour appears that indicated that reaction is positive. The sample then putted on micro plates and absorbance is noted by spectrophotometer at $532 \mathrm{~nm}[23]$.
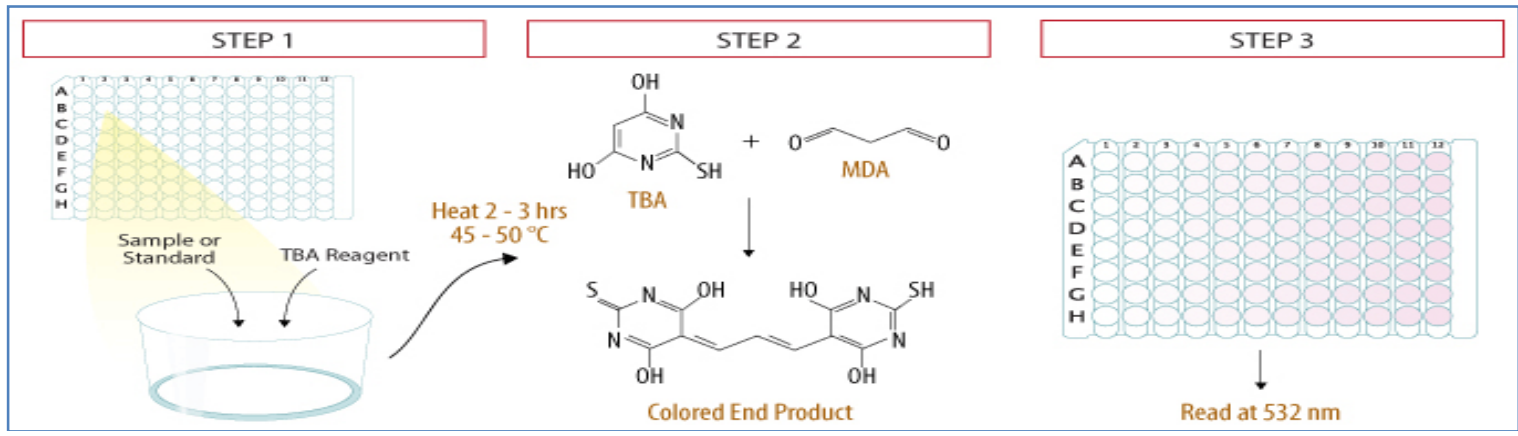

Fig-3: Thiobarbituric acid kit assay for determination of lipid peroxidation

\section{Detection of Root activity}

Root activity in plant tissues determined by using the triphenyltetrazolium chloride test. During this test, triphenyltetrazolium chloride detected or be appear as a red colour and enzyme dehydrogenase shows biological activity in the root of mitochondrial respiratory chain[24]. Root sample collected from plants, grinded into fine powder to make a thick paste for testing the root activity in plants[25]. The root activity in plants measured within twenty four to forty eight hours. The absorbance is then measured by spectrophotometer at absorbance $485 \mathrm{~nm}$. The most important parameter in this test is that keep avoiding the root samples with fungal infection. If no couour appear in the final sample, then there is no respiration and there is no staining because dehydrogenase appears only in red colour sample[26].

\section{CONCLUSION}

As accumulation of cadmium is crucial and important for investigating the Salix spp cuttings. This study dectedbe helpful for discovering the mechanism that under hydroponic conditions, phytoremediation plants show physiological and biochemical responses by nutritional supplementation of nitrogen and phosphorus in proper concentrations. This study dectedbe aid in discovering the biochemical basis of using the different concentrations of nitrogen and phosphorus for trapping of cadmium using salix plants. 


\section{REFERENCES}

1. Sugiura, M. (1992). The chloroplast genome. 10 Years Plant Molecular Biology.

2. Stern, D. B., Goldschmidt-Clermont, M., \& Hanson, M. R. (2010). Chloroplast RNA metabolism. Annual review of plant biology, 61, 125-155.

3. Ohyama, K., Fukuzawa, H., Kohchi, T., Shirai, H., Sano, T., Sano, S., ... \& Aota, S. I. (1986). Chloroplast gene organization deduced from complete sequence of liverwort Marchantia polymorpha chloroplast DNA. Nature, 322(6079), 572-574.

4. Alexander, T. J., Vonlanthen, P., \& Seehausen, O. (2017). Does eutrophication-driven evolution change aquatic ecosystems?. Philosophical Transactions of the Royal Society B: Biological Sciences, 372(1712), 20160041.

5. Rogers, S. O., \& Bendich, A. J. (1989). Extraction of DNA from plant tissues. In Plant molecular biology manual (pp. 73-83). Springer, Dordrecht.

6. Sachs, T. (2005). Pattern formation in plant tissues (Vol. 25). Cambridge University Press.

7. Rogers, S. O., \& Bendich, A. J. (1985). Extraction of DNA from milligram amounts of fresh, herbarium and mummified plant tissues. Plant molecular biology, 5(2), 69-76.

8. Smith, A. M., \& Zeeman, S. C. (2006). Quantification of starch in plant tissues. Nature protocols, 1(3), 1342-1345.

9. Kerk, N. M., Ceserani, T., Tausta, S. L., Sussex, I. M., \& Nelson, T. M. (2003). Laser capture microdissection of cells from plant tissues. Plant physiology, 132(1), 27-35.

10. Gezici, S. (2017). Proteomics techniques and their applications in cancer research. Türk Bilimsel Derlemeler Dergisi, 10(2), 54-61.

11. Lichtenthaler, H. K., \& Wellburn, A. R. (1983). Determinations of total carotenoids and chlorophylls $\mathrm{a}$ and $\mathrm{b}$ of leaf extracts in different solvents.

12. Niemczyk, P., \& Bendtsen, J. D. (2011). Improved coal grinding and fuel flow control in thermal power plants. IFAC Proceedings Volumes, 44(1), 7018-7023.

13. Bouché, C., Brandt, C., \& Broussaud, A. (2005). Advanced control of gold ore grinding plants in South Africa. Minerals Engineering, 18(8), 866876.

14. Shafiq, S., Adeel, M., Raza, H., Iqbal, R., Ahmad, Z., Naeem, M., ... \& Ahmed Azmi, U. R. (2019). Effects of Foliar Application of Selenium in Maize (Zea Mays L.) under Cadmium Toxicity. In Biological Forum-An International Journal (Vol. 11, No. 2, pp. 27-37).

15. Rao, K. M., \& Sresty, T. V. S. (2000). Antioxidative parameters in the seedlings of pigeonpea (Cajanus cajan (L.) Millspaugh) in response to $\mathrm{Zn}$ and $\mathrm{Ni}$ stresses. Plant science, 157(1), 113-128.

16. Richter, A. K., Frossard, E., \& Brunner, I. (2007). Polyphenols in the woody roots of Norway spruce and European beech reduce TTC. Tree physiology, 27(1), 155-160.

17. Naeem, M., Hayat, M., Qamar, A. S., Mehmood, T., Munir, A., Ahmad, G., ... \& Hussain, A. (2019). Risk factors, genetic mutations and prevention of breast cancer. Int. J. Biosci, 14(4), 492-496.

18. Aranguren, B., Becattini, R., Lippi, M. M., \& Revedin, A. (2007). Grinding flour in Upper Palaeolithic Europe $\quad(25000$ years bp). antiquity, 81(314), 845-855.

19. Simon, L. (2014). Potentially harmful elements in agricultural soils. In PHEs, Environment and Human Health (pp. 85-150). Springer, Dordrecht.

20. Naeem, M., Ali, J., Hassan, M. Z., Arshad, B., Rao, M. H. I., Sarmad, M. S. K., ... \& Hassan, M. U. (2019). Novel Approach Towards DNA Barcoding as a Tool in Molecular Biologyand Biological Activities of Cyclotides with Particular Emphasizes at Molecular Level. In Biological Forum-An InternationalJournal (Vol. 11, No. 2, pp. 83-96).

21. Ahmad, I., Khan, S., Naeem, M., Hayat, M., Azmi, U. R., Ahmed, S., .. \& Irfan, M. (2019). Molecular Identification of Ten Palm Species using DNA Fingerprinting. Int. J. Pure App. Biosci, 7(1), 4651.

22. Naeem, A., Saddique, S., \& Chand, S. A. (2019). Advancement and Future Directions towards Herbal Treatment for Various Diseases.

23. Naeem, M., Hussain, A., Azmi, U. R., Maqsood, S., Imtiaz, U., Ali, H., ... \& Ghani, U. (2019). Comparative Anatomical Studies of Epidermis with Different Stomatal Patterns in Some Selected Plants Using Compound Light Microscopy. International Journal of Scientific and Research Publications, 9(10), 375-380.

24. Liu, L., Ge, W., Bestel, S., Jones, D., Shi, J., Song, Y., \& Chen, X. (2011). Plant exploitation of the last foragers at Shizitan in the Middle Yellow River Valley China: evidence from grinding stones. Journal of Archaeological Science, 38(12), 3524-3532.

25. Ghani, U., Naeem, M., Rafeeq, H., Imtiaz, U., Amjad, A., Ullah, S., ... \& Qasim, F. (2019). A Novel Approach towards Nutraceuticals and Biomedical Applications.

26. Parvin, W., Othman, R., Jaafar, H., \& Wong, M. Y. (2016). Detection of phenazines from UPMP3 strain of Pseudomonas aeruginosa and its antagonistic effects against Ganoderma boninense. International Journal of Agriculture and Biology, 18(3). 